
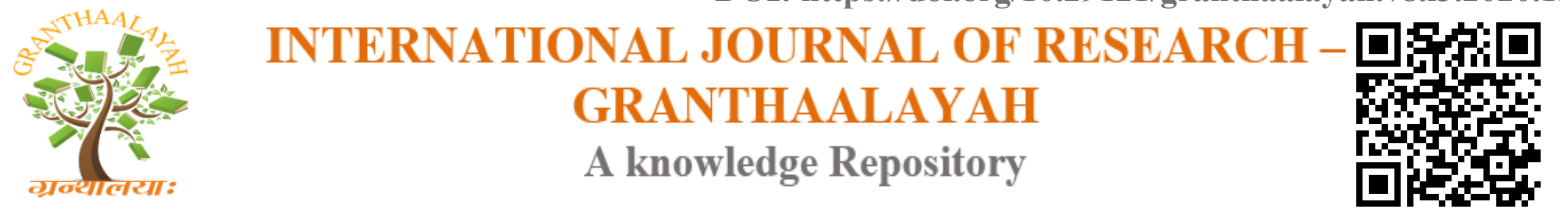

Science

\title{
FATE AND FREEWILL
}

\author{
Y. V. Subba Rao ${ }^{* 1}$ \\ ${ }^{* 1}$ University Science and Instrumentation Centre, Sri Venkateswara University, Tirupati, \\ Andhra. Pradesh, India
}

\begin{abstract}
The raison d'etre of human birth is liberation from bondage. Man appears to be practically a slave to the efforts of his past karma, but he is a free agent with regard to fresh and independent deeds. If these fresh and independent deeds resulting from his free will are in any manner directed to thwart the effects of his past karma, he seems to be doomed to failure. The acuteness of his failure seems to be proportionate to the disparity between the forces of fate and resisting will-power. On the other hand, if the fresh and the independent deeds are directed into neutral fields and neutral periods, the success appears to be proportionate to the force of the will and the effort put forward. It is through this free will, with which man responds to fate by deed and thought, that he stores up the good or bad karma for the life to come, in other words, elevates himself to obtain liberation from death or brings himself down from life to life encircling in the endless death-birth cycle. Today's freewill is tomorrow's destiny. While action is always present, the occurrence of reaction depends on the individual's motive and the action itself. It is this view of a harmonious combination of fate and free will that seems to account for the baffling inequities in life, while affording an answer to the perennial subject of Fate Versus Free Will.
\end{abstract}

Keywords: Karma; Purușārthas; Arishadvargas; Prarabdha; Agāmi; Sanchita; 3rd Law of Motion.

Cite This Article: Y. V. Subba Rao. (2020). "FATE AND FREEWILL.” International Journal of Research - Granthaalayah, 8(3), 147-155. https://doi.org/10.5281/zenodo.3733081.

\section{Introduction}

"All the Worlds a Stage,

And all the men and women merely players;

They have their exits and their entrances,

And one man in his time plays many parts,

His acts being seven ages. "----Shakespeare's

--- Shakespeare's 'As You Like It'[1]

It is often said that no one knows what determines the course of our lives? Whether our life paths are predetermined by a higher power or is there any space for freewill? Is it fate that rules our lives? Is there any reason in the happening of things? And if so, what is it? No one knows what 
kind of birth is possible in the next life if this chance is fritted away. A little thought given to it makes matters in this Universe logically clear. Spiritual life is not divorced from worldly life and hence it is a question of orienting one's life towards the goal of liberation and adopting the right way of performing action.

\subsection{The Two Schools of Thought}

Philosophers and religious heads have been debating for centuries in many a conference having the 'Fate vs. Freewill' as the central theme of conferences and finally they all ended in a fiasco and smoke. On one hand, there are those who believe in Fate and on the other hand, those of the opposite school, free will theorists who believe in Freewill. Fatalism is the belief that our decisions don't really matter. Those who belong to the school of fatalism hold that all events in human life, both important and insignificant, are preordained. They believe that even in the minutest events of life, man has no hand and that he is simply a creature of fate. In other words, they consider that there is no place for the free will of man in human life. To the fatalist, if he spoke rashly to a friend of his, if he forgot to post his letter, if he missed his bus, if he misplaced his snuffbox and if his wife did not salt the curry properly, nay, even if his child wept a little louder than usual, it is all fate and the result of nothing but fate.

On the other hand, those of the opposite school, free will theorists, believe that every individual is entirely responsible for everything that happens in his own life. There is no God and no destiny. Life is random. They hold that man is a thoroughly free agent, that there are no forces beyond his control, that he is completely responsible for his acts, that character is destiny, and that there is nothing impracticable to him, if only the right and the proper means are employed to achieve the desired object. o his friend of the other school, the free will theorist, if he would not live a thousand years, it was because he was not temperate; if his friend died of smallpox, it was because he was not vaccinated; if his father who was hale and healthy died suddenly and untimely without any apparent ailment, it was because his heart failed; nay, if he could not overthrow the present order of society, it was because he had not sufficient means at his command. No two views can be more diametrically opposed to each other.

\subsection{Relative Merits and Demerits of the Two Beliefs}

Without entering into any discussion of the relative merits of the two beliefs, it is obvious that both of them deserve to be characterized as thoroughly unsatisfactory. The extreme view of fatalism seems to be the result of the experience of several persons who have failed in their attempts, in spite of the employment of the right and proper means in achieving their objects. On the other hand, the extreme view of free will seems to be equally the result, of several persons who have succeeded in almost all their attempts and have complacently attributed their achievements to their own efficiency, characterizing their defeated brethren as lacking in some fundamental qualities which go to make for success in life. It is clear that the fatalist makes man a totally irresponsible being. He attributes every one of his acts to his previous karma. His previous karma is again attributed to his karma still more previous to that, and so on, until we are faced with the problem of man having been created with a certain amount of karma at the very first instance. This is a mischievous doctrine as such, pernicious to the extreme, and cannot be countenanced by any progressive society. It implicates the Creator himself and postulates invidious distinctions between 
man and man at the very beginning of creation of the human species. If a progressive society is to subscribe to this theory and follow it to its logical conclusions, all activity, both in the private and the public spheres, must come to a standstill.

At the same time, the free will theorist will realize the hollowness of his pretensions, if he sheds a little of his conceit and looks at the world around him, including himself, with plain glasses. He will find certain very well-projected efforts meeting with undeserved failure, and many effortless attempts meeting with undeserved success. He will also find the innocent and the righteous sometimes suffering, while the guilty and the wicked sometimes prospering. A little psychological self-analysis would reveal the absence of even handed justice in his own case. According to this doctrine, therefore, a child should be as little responsible for being born an heir-apparent to a throne, as it should be for being born blind or lame. The word 'accident' is the only answer that the free will theorist has to offer, when confronted with these baffling issues and inequities in life. It is not difficult to comprehend that this doctrine is still more pernicious than that of the fatalist. If accident is to explain the inequities in life, it will certainly be canvassed by both virtue and vice. Since punishment for murder would then be a matter of accident, depending upon the availability of evidence for conviction, the science and art of murder for profit may be advantageously studied. Ethical considerations would be wholly irrelevant in a world sustained by the theory of the survival of the fittest. It is obvious that a theory, which tends to set a premium on short cuts and vicious deeds, bereft of all ethical values and considerations, is a pernicious one in the extreme.

\title{
2. Objective Forces and Subjective Response
}

It is easy to demolish both the theories, but difficult to suggest an acceptable one. An attempt may, however, be made. Man is placed in an objective world, the stage in which he has to play his part. Every moment of his existence, he has to respond subjectively to his objective environment. The subjective response to the objective forces may take the form of co-operation, neutrality or opposition. These three forms of response may be active in deed or in thought, or in both. The field of astrology consists in revealing the objective forces at work on man, who has to respond subjectively to them. The objective forces for good or evil are indicated in the horoscope of the individual. The basic principle of astrology is that the objective forces for or against an individual are pre-determined. But astrology leaves the individual to respond to these forces in his own way with the aid of his free will. It is for the individual to respond by co-operation, neutrality or opposition, and by deed or thought or both. The nature of the response is entirely with the individual. The horoscope simply indicates the objective forces, for good or bad, their periods, their direction, and their strength. It follows that neutral fields and forces are also indicated [2]. Good actions lead to good birth and ipso facto bad actions lead to bad births. Thus, good actions or bad actions, they do not render liberation but leads into an eternal cycle of births and deaths. Good actions lead to good birth and ipso facto bad actions lead to bad births. Thus, good actions or bad actions, they do not render liberation but leads into an eternal cycle of births and deaths.

\author{
जातस्य हि ध्रुवो मृत्युर्ध्रुवं जन्म मृतस्य च । \\ तस्मादपरिहार्येऽर्थे न त्वम शोचितुमर्हसि ॥२-२७॥ \\ jātasya hi dhruvo mrityur dhruvain janma mritasya cha \\ tasmād aparihärye 'rthe na tvaì śhochitum arhasi II B.G.2-27 II [3]
}


Translation: Death is certain for one who has been born, and rebirth is inevitable for one who has died. Therefore, you should not lament over the inevitable.

The four Vedas envisage four objectives called Purusharthās for fulfilment of life. Karma means action of prescribed duties. But human beings work the whole life for the sole purpose of meeting endless list of material ends. Human birth is a precious gift granted after a long struggle of evolution and is the only vehicle for reaching enlightenment. It should not be wasted. The long cycle of transmigration, whose genesis is desire prompted action, can only be broken by understanding the nature of Self, which is not the body. While action is always in the present form, reaction can happen based on our motive and the action itself.

\section{The infallible law of action and reaction: Kanād's Third Law of Motion and Newton's Third Law of Motion}

Acharya Kaṇāda (Sanskrit: कणाद) was a Hindu sage and philosopher who was born in Prabhas Kshetra (near Dwaraka) in Gujarat, India. He composed his Sutras around 600 BCE. Vaishesika Sutras by Kanada describe Laws of Motion. Third law of Motion of Kanāda states:

\section{कणाद का गति का तीसरा नियम: (३) वेग: संयोगविशेषाविरोधी [4]}

\section{Meaning: Action and reaction are equal and opposite}

Sir Isaac Newton almost 1500 years later first presented his three laws of motion in the "Principia Mathematica Philosophiae Naturalis" in 1686. His third law states that for every action (force) in nature there is an equal and opposite reaction [5]. In other words, if object A exerts a force on object B, then object B also exerts an equal and opposite force on object A. A force is a push or a pull that acts upon an object as a result of its interaction with another object. These two forces are called action and reaction forces and are the subject of Newton's third law of motion. Formally stated, Newton's third law is: For every action, there is an equal and opposite reaction. This is not only true in Physics but equally true in Philosophy. This is the infallible law of action and reaction. An action is always in the present, but its reaction always in future; the future may be a moment, a few seconds, a minute, some hours or even eons later, depending on the nature of the action. Hence, the result occurs in the future. When the results are immediate, the law of cause and effect is clearly evident. For example, mosquito bite causes Typhoid fever whereas the result or reaction is may be time bound as in the cases of alcohol drinking, smoking, etc., leading to cancer [6].

\section{कर्मणयेवाधिकारस्ते मा फलेषु कदाचन। \\ मा कर्मफलहेतुर्भूर्मा ते सड़ेड स्त्वकर्मणि ॥ २-४७ \\ karmanyevādhikāraste mā phaleṣu kadācana I}

mā karmaphalaheturbhūrmā te sango'stvakarmaṇi II B.G. 2-47 [7]

Translation: To work alone you have the right, and not to the fruits. Do not be impelled by the fruits of work. Nor have attachment to inaction.

Do your duty, but do not concern yourself with the results. We have the right to do our duty, but the results are not dependent only upon our efforts. A number of factors come into play in 
determining the results - our efforts, destiny (our past karmas), the will of God, the efforts of others, the cumulative karmas of the people involved, the place and situation (a matter of luck), etc. Now if we become anxious for results, we will experience anxiety whenever they are not according to our expectations. The fruits of your actions are not for your enjoyment. To perform actions is an integral part of human nature. Having come into this world, we all have various duties determined by our family situation, social position, occupation, etc. While performing these actions, we must remember that we are not the enjoyers of the results - the results are meant for the pleasure of God.

Frequently, we see people working hard, with dedication and sincerity; despite all efforts, desired results are not obtained. The result of an action is based on two factors that are in our hands: our motive and the action itself. If you are performing a good action, with the noble motive of helping someone, the result is immediate - you feel happy and good about yourself. The moment you have an inappropriate thought or malicious intent and undertake wrong action, you may not get caught right away but agitation and discomfort arises in the mind immediately. Motives give results instantly while actions give results later.

Why do good people suffer? It appears sometimes that virtuous actions produce adverse results. Does the law of action and reaction really work then? Our understanding of this law is actually very limited. If we say it is merely chance, and that if we could somehow calculate or predict the right permutations and combinations, we would get our desired result, then logically, the world would be chaos. All sciences would fail if the law were erratic - and the latter could not be a law, after all! While the law can be perceived and spoken of in the broadest terms, no amount of mathematics or even pure science can justify it in its minutiae. We can only seek to acknowledge that the destiny we are experiencing today is the result of our past actions. There can be no effect or result without a cause, no fruit without a seed; nothing ever happens to us that isn't a consequence of some action we had done in the past whether long ago or recently. So we need to accept events with greater composure and peace of mind. The moment we acknowledge that the cause was our own actions in the past, and the future is dependent on our present actions, we are in control and can handle any situation effectively. We alone are responsible for our joy and happiness. When we blame somebody else for our sorrow, we become powerless and dependent. We cannot resolve the problem until the other person changes his attitude and stops 'giving' us unhappiness, so to speak. Once we have understood the law of action and reaction, we can own up our responsibility, find any situation easier to accept and be empowered to make a change. Life always throws up situations - the result of our past actions - which we refer to as destiny. What you do with it, and more importantly, how you face it, is a matter of choice.

\subsection{The Theory of law of fate: Amplified and Exemplified}

The theory thus stated, requires to be amplified and exemplified and it cannot be better done than by a study of the theory as manifested by, and portrayed in, the play of Macbeth by Shakespeare. If you are told that you will become a King, when you have apparently, no chance, you may leave the prophecy to shape itself and exclaim with Shakespeare's Macbeth,

"If chance will have me king, why, chance may crown me,

Without my stir." [8] 
and stick to your determination. Or, you may murder the king and usurp the crown as Macbeth finally did. The prophecy is fulfilled in either case, but the subjective response widely differs and stores up the relevant karma. The first attitude taken up by Macbeth to the promise to kingship, and his resistance to every wicked mental image of the possibilities of getting at the crown, was a subjective response of the noblest order, not by deed but by thought. It was a response, which must store up a good karma. Before he committed the murder of his king, he was afflicted with compunctions of conscience. He exclaimed,

"He's here in double trust:

First, as I am his kinsman and his subject, Strong both against the deed: then, as his host, Who should against his murderer shut the door,

Not bear the knife myself'.[9]

He felt that it was the bloody business that oppressed his mind with the fatal vision of the dagger before the murder. After the event, he said to his wife that his bloody hand presented a sorry sight. He also said to her that he had most need of blessing at the time of the perpetration of the deed and, when someone at the most cried in his sleep "God bless us", the word 'Amen' stuck in his (Macbeth's) throat. He carried with him by mistake the daggers, which he should have left with the sleepy grooms. Lady Macbeth took him to task and when she bade him go, carry them and smear the sleepy grooms with blood, Macbeth said that he would go no more, that he was afraid to think of what he had done and that he dared not look on it again. Every noise appalled him. His hands appeared to pluck out his eyes. The great ocean would not be sufficient to wash the blood clean from his hand. Macbeth did really repent for his foul deed. To that extent, he must be deemed to have rendered sin of the murder of his king less heavy than it should otherwise be. In active deed, his subjective response to the prophecy of kingship was one of cold-blooded murder. But his subjective response was one of tragic conflict before the murder and of sincere remorse after it. If the deed be $\mathrm{X}$ and his mind $\mathrm{Y}$, his evil karma resulting from his response by deed and thought was $\mathrm{X}$ minus $\mathrm{Y}$.

The evil karma of Lady Macbeth may be assessed similarly with reference to this murder. She was acquainted by Macbeth of prophecy and, by the messenger, that the king would come to her castle for a night's stay. She invoked the spirits that tend on mortal thoughts and desired to be unsexed. She prayed the spirits to see that no compunctious visitings of nature shook her fell purpose. When Macbeth told her that Duncan would leave the place the next morning, she exclaimed that never should Sun that morrow see. She fired his ambition with her reproaches. If he did not do the deed, he had no love for her. She called him a coward and a poor cat in the adage. After the murder, she played her part superbly. She swooned to show that she was horrified to find such a deed committed in her house. Were it not for her instigation, Macbeth would not have committed the murder. She was in fact the principal. She added a remorseless thought to the deed. Her subjective response to the prophecy in deed and thought was X plus $\mathrm{Y}$ of sin as against $\mathrm{X}$ minus $\mathrm{Y}$ of her husband.

The story of Macbeth illustrates the subjective response of an individual to fate, not only by active cooperation, but also by neutrality as well as by active opposition. The witches prophesied that Macbeth would become the Thane of Cawdor, that he would become the king, that no person born 
of woman could harm him, that he must beware of Macduff, that he would never be vanquished until great Birnam Wood should come to high Dunsinane Hill against him, and that Banquo's issue would reign in Scotland. Quite agreeably to the prophecy, the Thane of Cawdor was executed for treason and Macbeth was made the Thane of Cawdor without the least stir on his part. Shakespeare, however, does not even suggest (and it is not the function of the artist, as he was) how Macbeth could have become the King, if he had not chosen to actively respond to the prophecy by murdering the king. If fate would have him king, fate would certainly have crowned him without his stir, as fate made him the Thane of Cawdor, but Macbeth chose to actively co-operate by murder. He actively opposed the prophecy with regard to Banquo's issue by attempting to have Banquo and his son, Fleance, murdered. In the attempt, Fleance escaped and the issue of Banquo reigned in Scotland after Macbeth. He tried to do away with Macduff, but the latter ran away to England. He failed in his active opposition to fate, which would have Banquo's issue as kings after Macbeth and which reserved Macduff to be the only man whom Macbeth had to beware.

Macduff led an army against Macbeth. But Macbeth was not afraid. He thought that even Macduff was born of woman and that it was impossible for Birnam Wood to move. He was sure that he would live the lease of nature and pay his breath to time and mortal custom. Every soldier in the army of Macduff hued down a bough from the trees of Birnam Wood and bore it before him, so that Macbeth may not be apprised of the numbers of the invading army. Macbeth's messengers thought that Birnam wood began to move and reported so to him; he called them liars and slaves. Indeed, Birnam Wood was moving to Dunsinane. But even Macduff was born of woman and who was there that was not born of woman. Macbeth fought with a contempt for swords and weapons brandished by men that were born of woman. Macbeth, however, avoided Macduff, but finally had to meet him. He told Macduff that he bore a charmed life and that he would not yield to one born of woman. But Macduff replied that from his mother's womb he was untimely ripped. Macbeth cursed the witches who kept the word of promise to his ear and broke it to his hope. He fought and was killed by Macduff. Fate had its way whether Macbeth co-operated, opposed, or kept himself neutral.

\subsection{The Theory of law of fate: Examples from Indian Mythology}

Indian mythology contributes a very pointed instance of active response to fate by opposition. Kamsa gave his sister, Devaki, in marriage to Vasudeva. After the marriage, Kamsa himself drove the married couple to the bridegroom's house. On the way, a miraculous voice from the heavens declared that he might rejoice over the marriage but that the eighth issue of his sister would slay him. At once Kamsa pounced upon his sister with his sword. Vasudeva interfered and prayed his brother-in-law to spare the life of the woman, promising to put into his hand each child as it was born. For the time being, Kamsa spared the life of his sister, but imprisoned the couple subsequently. He was doing away with each child as it was born. The eighth issue was Sri Krishna. At the same time when Krishna was born, one Yaśoda gave birth to a female child and was lying in an unconscious state after delivery. Vasudeva, fearing Kamsa's hand over the babe, carried his male child to Yaśoda, and exchanged the child for the female child of the latter. Kamsa, coming to know of the birth of child to his sister, entered the room of Devaki, and in spite of the prayers of his sister and brother-in-law, lifted up the child and threw it up right into the air to descend on his drawn sword. The child, instead of descending, stood up in space over him and said that the 
one who was to slay him was a boy who was growing up elsewhere. Thereafter, the female child disappeared in the sky. In due course, Krishna grew up to slay his maternal uncle, Kamsa [10].

\section{The Functioning of Fate}

Following the line of thought, it is not difficult to see that the subjective response of man to objective forces would be merely groping in the dark, when he is not armed with a previous knowledge of these objective forces, to which he may happen to be subjected during any given period of his life. Neither this discussion nor the subject of astrology is, of course, of any avail to persons who would take life as it comes. On the other hand, these are of interest only to persons who desire to be intelligently and beneficially forearmed with a knowledge of the future. It is human nature to try to actively oppose the impending evil and to actively co-operate with the promised good. But the wise man, who would be benefited by foreknowledge, will not spend himself out either in vainly opposing a strong current of evil objective forces of a definite character, or in unnecessarily co-operating with a strong current of favourable objective forces of an equally definite character. On the other hand, armed with foreknowledge, the wise man will devote all his energies to achieve his desired object during periods when the objective forces are neutral. The point is that strong objective forces of evil resulting from previous karma, as indicated in the horoscope, can never be thwarted by any amount of active opposition. Similarly, a host of enemies cannot upset or obstruct a strong current of favourable forces in store. The law of fate is both inflexible and inexorable and exacting in its operation. Man reaps what he has sown and will reap what he sows.

\section{Conclusions}

Man appears to be practically a slave to the efforts of his past karma, but he is a free agent with regard to fresh and independent deeds. If these fresh and independent deeds resulting from his free will are in any manner directed to thwart the effects of his past karma, he seems to be doomed to failure. The acuteness of his failure seems to be proportionate to the disparity between the forces of fate and resisting will-power. On the other hand, if the fresh and the independent deeds are directed into neutral fields and neutral periods, the success appears to be proportionate to the force of the will and the effort put forward. It is through this free will, with which man responds to fate by deed and thought, that he stores up the good or bad karma for the life to come, in other words, elevates himself or brings himself down from life to life. Today's freewill is tomorrow's destiny. It is this view of a harmonious combination of fate and free will that seems to account for the baffling inequities in life, while affording an answer to the perennial subject of Fate Versus Free Will. If the fresh and the independent deeds are directed towards the path of Arishadvargas, he will be doomed to failure. It is through this free will, with which man responds to fate by following the path of Purușārthas or Arishadvargas that he stores up the good or bad karma for the life to come [11].

Karma is of three kinds, Sanchita or the accumulated work, Prārabdha or the fructifying works and Kriyamana or the current works. Sanchita is all the accumulated karmas of the past. Part of it is seen in the character of man, in his tendencies and aptitudes, capacities, inclinations and desires. Prārabdha is that portion of the past karma that is responsible for the present body. It is ripe for 
reaping. It cannot be avoided or changed. It is only exhausted by experiencing. You pay your past debts.

Kriyamana is that karma which is now being done for the future. It is also called $\overline{A g} \bar{a} m i$ or Vartamāna. In the Vedāntic literature, there is a beautiful analogy. The bowman has already sent an arrow, it has left his hands. He cannot recall it. He is about to shoot another arrow. The bundle of arrows in the quiver on his back is the Sanchita. The arrow he has shot is Prärabdha. And the arrow he is about to shoot from his bow is $\overline{A g a m i}$. Of these, he has perfect control over the Sanchita and $\overline{A g a m i}$, but he must surely work out his Prārabdha in this life. God has endowed man with free will and hence he can make the best of all circumstances and desist from again indulging in acts contrary to Dharma.

\section{Acknowledgements}

I profusely thank my son, Professor. Y. V. Ramana Rao, M.Tech., Ph.D., and all my friends for their continued support and encouragement in bringing out this research paper.

\section{References}

[1] William Shakespeare, "As You Like It" (2018), Fingerprint Publishing, ISBN-10: 9387779610; ISBN-13: 978-9387779617

[2] Rao, Y.H. and Rao, Y.V.S. (2004), "Astrology on the Moving Zodiac - The One System for the East and the West", Author's Publication. ISBN 81-7525-939-66 Review: (Extract from 'ASTROLOGY', The Astrologers' Quarterly, England, Vol.56, No.1, Spring 1982)

[3] https://www.holy-bhagavad-gita.org/chapter/2/verse/27

[4] Venkata Subba Rao, Yeragudipati (2017) "Science in Sanskrit Verses of Vedic Scriptures", Lambert Academic Publications, West Germany.ISBN 978-620-2-06829-1 and Prabhu, C. S. R, The Physics of Vaisesika, (2014), Publisher: Sri Venkateswara Vedic University, Tirupati, India; ISBN-10: 9381887268; ISBN-13: 978-9381887264

[5] openstax.org > books > college-physics > pages > 4-introduction-to-dyn... Introduction to Dynamics: Newton's Laws of Motion - College

[6] Rao, Y.V.S, (2016), Is the Nala-Damayanti Episode of Tretayuga a Premonition of Kuru-Pandava story of Dvaparayuga in Miniature --- Veda Darshini International Monthly Research Journal (electronic version) iii Issue December 2016

[7] https://www.holy-bhagavad-gita.org/chapter/2/verse/47

[8] William Shakespeare, "Macbeth" (2018), Fingerprint Publishing, ISBN- ISBN10: 9788175994195; ISBN-13: 978-8175994195; ASIN: 8175994193

[9] William Shakespeare, "Macbeth" (2018), Fingerprint Publishing, ISBN- ISBN10: 9788175994195; ISBN-13: 978-8175994195; ASIN: 8175994193

[10] Srimad Bhagavatam (Bhagavata Purana) - Complete ...bhagavata.org > downloads > bhagavatacompl

[11] Rao. Y. V. S (2013), The choice of life is yours: Puruşārthas or Arishadvargas Journal of Advances in Philosophy, www.cirworld.com, Vol. No.2. No.1: JAPY Pp48-53

* Corresponding author.

E-mail address: yv subbarao2004@y yhoo.com 